\title{
Kearifan Lokal Etnis Sasak dalam Cerita Rakyat Monyeh
}

\begin{abstract}
Nuryati $^{1}$
Abstrak

Etnis Sasak seperti halnya etnis-etnis yang lainnya mempunyai identitas dan keunikan sendiri. Bahasa Sasak yang merupakan identitas etnis Sasak sampai sekarang masih memiliki fungsi praktis sebagai alat komunikasi, yaitu dipergunakan dalam komunikasi sehari-hari oleh penuturnya. Hal tersebut terbukti dari penggunaan bahasa Sasak dalam berbagai aspek kehidupan masyarakat penuturnya, seperti pembicaraan dalam lingkungan keluarga, masyarakat, kantor, dan masih ada yang menggunakannya sebagai bahasa pengantar di lingkungan sekolah. Di samping berfungsi sebagai alat komunikasi, bahasa Sasak juga berfungsi sebagai alat pengungkap rasa seni. Hal ini dapat dilihat dalam aktivitas sastra seperti bekayaq, wayang sasak, lelakaq, cilokaq, dan tradisi lisan lainnya yang menggunakan bahasa Sasak sebagai media pengungkapnya. Masyarakat Sasak seperti juga masyarakat etnis lain mempunyai beragam sastra lisan, seperti pantun, mantra, syair, dan cerita-cerita rakyat (prosa). Sastra lisan Sasak sebagai bagian dari kebudayaan yang pernah hidup dan berkembang di tengah-tengah masyarakat, tentu mempunyai fungsi dan kedudukan di tengah-tengah masyarakat penuturnya, seperti sebagai sarana penghibur, pendidikan, dan komunikasi. Sebagai salah satu ragam sastra lisan yang dimiliki oleh suku Sasak di Pulau Lombok, cerita rakyat merupakan kekayaan budaya yang mengandung nilai-nilai budaya bagi masyarakat penuturnya.
\end{abstract}

Kata kunci: nilai budaya, kearifan, cerita rakyat

\section{Pendahuluan}

Etnis Sasak merupakan etnis asli di Pulau Lombok ini mempunyai identitas dan kekhasan tersendiri. Menurut Liliweri (2005), etnis dapat diartikan sebagai setiap kelompok sosial yang ditentukan oleh ras, adat-istiadat, bahasa, norma dan nilai budaya, dan lainnya. Identitas etnis Sasak dapat ditunjukkan oleh bahasa daerah yang digunakan oleh masyarakat tuturnya yaitu bahasa Sasak. Bahasa Sasak sampai sekarang masih memiliki fungsi praktis sebagai alat komunikasi, yaitu dipergunakan dalam komunikasi sehari-hari oleh

\footnotetext{
${ }^{1}$ Pembantu Pimpinan pada Kantor Bahasa Provinsi NTB
} 
penuturnya. Hal tersebut terbukti dari penggunaan bahasa Sasak dalam berbagai aspek kehidupan masyarakat penuturnya, seperti pembicaraan dalam lingkungan keluarga, masyarakat, kantor, dan masih ada yang menggunakannya sebagai bahasa pengantar di lingkungan sekolah.

Di samping berfungsi sebagai alat komunikasi, bahasa Sasak juga berfungsi sebagai alat pengungkap rasa seni. Hal ini dapat dilihat dalam aktivitas sastra seperti bekayaq, wayang sasak, lelakaq, cilokaq, dan tradisi lisan lainnya yang menggunakan bahasa Sasak sebagai media pengungkapnya. Masyarakat Sasak seperti juga masyarakat etnis lain mempunyai beragam sastra lisan, seperti pantun, mantra, syair dan cerita-cerita rakyat (prosa).

Sastra lisan Sasak sebagai bagian dari kebudayaan yang pernah hidup dan berkembang di tengah-tengah masyarakat, tentu mempunyai fungsi dan kedudukan di tengah-tengah masyarakat penuturnya, seperti sebagai sarana penghibur, pendidikan, dan komunikasi. Sebagai salah satu ragam sastra lisan yang dimiliki oleh suku Sasak di Pulau Lombok, cerita rakyat merupakan kekayaan budaya yang mengandung nilai-nilai budaya bagi masyarakat penuturnya

\section{Pembahasan}

Setiap etnis mempunyai kekayaan sastra dengan berbagai jenisnya. Kekayaan sastra yang dimiliki oleh etnis Sasak salah satunya adalah prosa atau cerita rakyat. Dari sekian banyak cerita rakyat etnis Sasak, salah satunya adalah Monyeh. Cerita Monyeh ini menggambarkan seorang pangeran yang mengubah dirinya menjadi seekor monyet (dalam bahasa Sasak disebut monyeh) untuk menyelamatkan seorang putri yang disia-siakan oleh raja yang berkuasa di Pulau Lombok dan saudara-saudaranya.

Karya sastra yang banyak dimiliki oleh etnis Sasak berupa lontar. Cerita Monyeh ini juga terdapat dalam lontar yang disebut Lontar Monyeh. Adapun ringkasan cerita Monyeh adalah sebagai berikut:

Pada zaman dahulu, di bumi Nusantara ini, ada tiga orang raja bersaudara, yaitu Raja Indarapandita, Raja Indrasekar, dan Raja Layangsari. Raja Indrapandita berkuasa di Pulau Lombok, Raja Indrasekar berkuasa di Pulau Jawa, dan Raja Layangsari berkuasa di Pulau Madura.

Raja Layangsari mempuyai dua orang anak, laki-laki dan perempuan. Anak laki-lakinya bernama Jayangsekar dan anak perempuannya bernama Ratna Ayu Windusari. 
Raja Indrapandita mempunyai sembilan orang anak perempuan. Anak paling sulung bernama Denda Wingit, sedangkan anak paling bungsu bernama Ratna Ayu Wideradin. Paras Ratna Ayu Wideradin sangat cantik sehingga membuat iri hati kedelapan saudaranya. Untuk itu, Denda Wingit dan saudarasaudaranya menghasut ayahanda mereka agar Denda Wideradin, si bungsu, tidak diperhatikan dan disayangi lagi.

Ratna Ayu Wideradin pun akhirnya dikucilkan di sebuah pondok yang sangat sederhana, bertiang bambu di dalam taman bersama inang pengasuhnya yang bernama Rangda Sayoman. Pakaiannya hanya yang melekat di badan, terbuat dari kain hitam kasar. Selendangnya terbuat dari kain tenun berwarna hijau yang sudah usang. Selendang itu dipakai untuk selimut tidur dan penutup dada. Makannya tidak tentu, sehari makan sehari tidak makan. Begitulah kesengsaraan Ratna Ayu Wideradin yang hidup di dalam taman. Ia dijuluki oleh Rangda Sayoman dengan nama Denda Winangsia, artinya putri yang tersia-sia. Hal ini sangat berbeda dengan keadaan kedelapan saudaranya. Mereka hidup penuh dengan kemewahan dan segala keinginannya terpenuhi.

Raja Indrasekar yang berkuasa di Pulau Jawa mempunyai dua orang anak laki-laki. Anak sulung bernama Raden Witasari yang menjadi putra mahkota sebab ia lahir dari permaisuri utama. Anak bungsu bernama Raden Kitapmuncar, anak dari permaisuri kedua. Raden Kitapmuncar menjadi pengeran penawing atau pangeran kelas dua.

Hari-hari Ratna Ayu Wideradin atau Denda Winangsia dihabiskan berdua dengan inang asuhnya. Suatu hari, Denda Winangsia minta kepada inangnya untuk membelikan dua lembar kertas. Harga kertas itu dua puluh lima kepeng. Rangda Sayoman yang sangat menyayangi Denda Winangsia segera pergi membelikan apa yang dimintanya. Setelah itu, kertas itupun diserahkan kepada sang putri. Denda Winangsia segera membuat lukisan dirinya pada kertas itu. Lukisannya sangat indah, persis dengan keadaan aslinya.

Terlukislah wajah Denda Winangsia yang cantik jelita sedang duduk bersedih di pondoknya yang buruk. Pakaian di tubuhnya tampak lusuh dan lapuk. Di kertas kedua dituliskannya sebuah syair yang menuturkan kesengsaraan hidupnya. Tercantum pula nama ayah dan ibunya serta kedelapan saudara-saudaranya itu. Bukan main indahnya syair itu dan sangat memilukan hati orang yang membacanya.

Pada saat Denda Winangsia sedang asyik melukis dan membuat syair itu, tiba-tiba datanglah angin kencang menyambar kertas itu. Angin membawa 
kertas itu terbang ke angkasa jauh melayang. Akhirnya, kertas itu jatuh di Taman Sari Kerajaan Indrasekar. Kedua lembar kertas itu tersangkut di tepi pancuran mandi putra raja. Kebetulan putra Raja Indrasekar, Raden Witarasari, pergi mandi bersama adiknya, Raden Kitapmuncar. Para abdi dan pengiring lain ikut pula.

Sesampai di Taman Sari pergilah Raden Witarasari menuju pancuran. Gambar dan syair Denda Winangsia ditemukan Raden Witarasari. Lalu, ia memperhatikan lukisan itu dan dibacanya syair yang tertera di kedua lembar kertas itu. Tidak terkira sedih hati Witarasari sampai ia tidak sadarkan diri. Raden Kitapmuncar segera menolongnya dan dibacanya pula surat itu. Tahulah ia bahwa Raden Witarasari pingsan karena sedih setelah mengetahui perihal sepupunya di negeri Indrapandita. Sudah lama ia mendapatkan kabar dari para nahkoda kapal bahwa ada seorang putri raja yang amat cantik. Putri raja itu disia-siakan oleh ayahandanya karena selalu difitnah oleh kedelapan saudaranya.

Setelah sadar, Raden Witarasari segera pulang ke istana untuk melaporkan kepada ayahandanya. Ia meminta kepada adiknya yang sakti, Kitapmuncar, untuk dibuatkan kapal dagang yang besar. Raden Kitapmuncar menyanggupi kehendak putra mahkota. Kemudian, Raden Kitapmuncar mengeluarkan cemeti wasiatnya. Sekali lecut terbelahlah alun-alun di depan istana menjadi sungai besar. Dari lecutan kedua tiba-tiba tercipta sebuah kapal dagang besar bertiang tiga. Haluannya berukir kepala singa lengkap dengan layar dan bendera. Kapal itu tidak ubahnya kapal dagang kompeni.

Raden Kitapmuncar memerintahkan rakyatnya untuk menaikkan barang dagangan. Keesokan harinya, berangkatlah kapal itu dengan nahkoda Raden Kitapmuncar.

Setelah berhari-hari berlayar, sampailah mereka di negeri Indrapandita, Kitapmuncar turun ke darat menemui syahbandar. Ia menyuruh syahbandar memberitahu raja bahwa kapal dagang besar telah datang membawa barangbarang dengan harga murah. Ia memperkenalkan diri dengan nama Nahkoda Jamal Malik dari negeri seberang.

Benarlah pada keesokan harinya datanglah raja ke pantai bersama delapan orang putrinya. Raden Witarasari sengaja menyediakan sembilan kursi di pantai. Ketika ia meneropong ke pantai dan dilihatnya hanya delapan kursi yang terisi, tahulah ia bahwa memang benar Ratna Ayu Wideradin disia-siakan. Ratna Ayu Wideradin alias Denda Winangsia menyuruh Rangda Sayoman pergi 
ke pantai untuk berbelanja. Karena uangnya hanya enam puluh kepeng, ia berpesan agar dibelikan barang-barang yang murah.

Jual beli di pantai itu sangat ramai. Raja membeli bermacam-macam barang mahal untuk delapan putrinya. Saat itu datanglah Rangda Sayoman ingin membeli barang berharga murah. Raden Kitapmuncar yang sakti segera tahu bahwa Rangda Sayoman adalah pengasuh Denda Winangsia. Ia kemudian cepat melapor ke kapal. Mendengar berita bahwa pengasuh Winangsia mencari barang berharga murah sekitar enampuluh kepeng, Raden Witarasari langsung mengubah dirinya menjadi kera (dalam bahasa Sasak disebut monyeh).

Si Monyeh yang sudah dibayar Rangda Sayoman segera dibawa pulang ke Taman Sari. Alangkah senang hati Winangsia mendapat binatang mainan itu. Lagi pula, si Monyeh pandai berkata-kata seperti manusia. Cara bicaranya lucu dan pintar. Para penjaga taman, Papuq Cungklik dan Amaq Buwuh, ikut senang. Putri Winangsia sangat sayang kepada si Monyeh. Ke mana saja ia pergi, si Monyeh selalu dibawa. Mereka makan bersama, tidur bersama, dan pergi mandi bersama. Tidak sejenak pun si Monyeh terpisah darinya.

Pada suatu malam, si Monyeh diam-diam pergi ke kapal. Ia menyuruh Raden Kitapmuncar membawa pakaian-pakaian yang indah ke Taman Sari. Denda Winangsia heran melihat pakaian-pakaian itu. Ia mengira si Monyeh bisa main sulap.

Mendengar berita bahwa Denda Winangsia mempunyai seekor kera yang sangat cerdik, timbullah rasa iri kedelapan saudaranya. Denda Wingit menyuruh patih untuk mengambil kera itu di Taman Sari. Denda Winangsia tidak mau memberikan si Monyeh kepada siapa pun, walau ia dibunuh sekalipun. Mereka mengatur siasat dengan mengatakan bahwa ayahanda meminta mereka untuk menari bersama di pendapa. Winangsia diminta berpakaian seperti mereka. Jika tidak, ia akan dibunuh oleh patih. Tentu saja Winangsia sangat sedih menerima perintah itu. Ia tidak punya pakaian tari seperti kakak-kakaknya. Melihat Winangsia bersedih, si Monyeh segera membujuknya.

"Sabarlah, Putriku. Saudara Tuan ingin mencelakakan Tuanku. Namun, Tuhan Maha Tahu siapa yang lurus dan siapa yang bengkok hatinya," kata si Monyeh.

Malam harinya diam-diam si Monyeh pergi ke kapal. Ia memerintahkan para abdinya membawa pakaian tari dan harta benda lain yang tidak ternilai harganya kepada Denda Winangsia. Denda Winangsia disuruh memakai busana 
itu. Ternyata, ia tampil sangat mempesona. Kedelapan saudaranya tercengang melihat penampilannya yang sangat anggun.

Pada suatu malam, ketika si Monyeh pergi ke kapal, Denda Winangsia menemukan mantel kera di dalam peti. Ia tahu kalau mantel itu milik si Monyeh. Mantel itu kemudian dibakar oleh Denda Winangsia. Tidak lama kemudian, datanglah seorang pangeran yang amat tampan. Ternyata, pengeran itu ialah Raden Witarasari, si kera palsu. Denda Winangsia sangat gembira ketika tahu bahwa si Monyeh adalah sepupunya yang menyamar menjadi kera. Akhirnya, keduanya memutuskan untuk membina kehidupan rumahtangga bersama. Pesta perkawinan mempelai berdua dilaksanakan diselenggarakan selama sembilan hari dengan pesta yang sangat meriah dengan melibatkan seluruh rakyat di wilayah kerajaan.

Setiap sebuah karya sastra seperti cerita rakyat selalu mempunyai nilainilai yang akan disampaikannya karena sebuah karya sastra merupakan refleksi dari kejadian-kejadian yang ada di masyarakat tertentu. Seperti halnya cerita rakyat Monyeh yang dimiliki oleh etnis Sasak ini mempunyai nilai-nilai budaya yang ditunjukkan masyarakat Sasak itu sendiri. Nilai-nilai budaya yang terdapat dalam cerita rakyat tersebut dihubungkan dengan lima hakikat dasar kehidupan manusia yaitu hubungan manusia dengan Tuhan, hakikat hubungan manusia dengan sesama, hakikat hubungan manusia dengan waktu, hakikat hubungan manusia dengan karya, dan hakikat hubungan manusia dengan alam.

Hakikat dasar hubungan manusia dalam kehidupan yang terdapat dalam cerita rakyat Monyeh adalah sebagai berikut.

\subsection{Hakikat Hubungan Manusia dengan Tuhan}

Hakikat hubungan manusia dengan Tuhan dapat direfleksikan dalam banyak hal antara lain keyakinan manusia akan Tuhan dengan segala kebesarannya dan melakukan perbuatan-perbuatan kebaikan yang mengacu pada segala perintah serta menjauhi perbuatan-perbuatan yang menjadi larangan Tuhan sesuai petunjuk yang terdapat pada kitab suci. Keyakinan manusia akan kebesaran Tuhan dalam cerita rakyat Monyeh terlihat pada bagian:

.... Mereka mengatur siasat dengan mengatakan bahwa ayahanda meminta mereka untuk menari bersama di pendapa. Winangsia diminta berpakaian sama seperti mereka. Jika tidak, ia akan dibunuh oleh patih. Tentu saja Winangsia sangat sedih menerima perintah itu. Ia tidak punya pakaian tari seperti kakakkakaknya. Melihat Winangsia bersedih, si Monyeh segera membujuknya. 
"Sabarlah, Putriku. Saudara Tuan ingin mencelakakan Tuanku. Namun, Tuhan Maha Tahu siapa yang lurus dan siapa yang bengkok hatinya," kata si Monyeh....

Bagian cerita itu menggambarkan secara eksplisit bagaimana si Monyeh memberikan nasihat kepada Denda Winangsia ketika sedang bersedih karena akan dicelakakan oleh saudara-saudaranya. Si Monyeh mengatakan bahwa Denda Winangsia mesti bersabar, Tuhan Maha Tahu siapa yang lurus dan siapa yang bengkok hatinya. Ungkapan itu menggambarkan bahwa ketika menghadapi segala permasalahan-permasalahan dalam kehidupan harus dengan sikap sabar, meski terkadang permasalahan tersebut dirasakan berat sekali untuk dihadapi. Dan terlepas dari semua itu, selalu ada tempat berlindung dan memohon kekuatan untuk mengadukan dan menyerahkan segala permasalahan itu, yaitu kepada Tuhan. Karena Tuhan Maha Tahu mana umatnya yang berhati baik dan berhati bengkok. Manusia yang berhati baik meskipun terkadang mengalami penderitaan pada akhirnya akan menemui kebaikan juga.

Etnis Sasak yang mendiami Pulau Lombok ini mayoritas menganut ajaran Islam. Bangunan masjid-masjid besar dan megah bisa ditemui hampir di setiap kampung. Keberadaan masjid-masjid itu telah membuat Pulau Lombok dijuluki dengan sebutan Pulau Seribu Masjid. Keberlangsungan kehidupan sehari-hari etnis Sasak banyak diwarnai dengan pengaruh ajaran Islam. Sesuai dengan ajaran Islam, orang Sasak sangat menjaga agar shalatnya tetap tegak. Apapun yang sedang dikerjakan bila terdengar adzan maka akan segera bergegas pergi ke masjid-masjid yang sangat banyak bertebaran sehingga mudah dijangkau. Semangat membangun masjid di kalangan orang Sasak tidak ada duanya. Ada pandangan bahwa membangun masjid merupakan "tiket" untuk melaju ke surga. Sumbangan yang dikeluarkan bagi pembangunan sarana ibadah ini dipandang sebagai investasi dengan ganjaran "kebun akhirat", begitu kira-kira pemahaman simpel masyarakat dalam perkara mendirikan masjid. Sumbangan yang diberikan bisa berupa uang, bahan material, keterampilan tenaga bangunan (pertukangan) atau bahkan sumbangan berupa tenaga. Selain itu, ada tradisi unik dan menarik, yaitu suatu ketika panitia pembangunan masjid akan menggelar majelis ta'lim dengan mengundang seorang pemuka agama yang disebut Tuan Guru untuk berdakwah di masjid yang akan dibangun. Hal itu dilakukan untuk menarik jamaah yang datang lebih banyak sehingga bantuan untuk pembangunan masjid pun akan banyak terkumpul. Semangat itu yang 
akhirnya menumbuhkan banyaknya masjid di pulau Lombok sehingga dikenal dengan sebutan Pulau Seribu Masjid (Windia, 2006)

Dalam kehidupan masyarakat Sasak sangat kental dengan pengaruh agama Islam. Hal tersebut dapat dibuktikan bagaimana masyarakat Sasak dalam menyambut dan memeriahkan peringatan hari besar seperti Maulid, Lebaran Ketupat, dan rangkaian prosesi untuk ibadah haji. Pada peringatan Maulid Nabi Muhammad Saw., masyarakat benar-benar menyambut dengan suka cita bahkan terlihat melebihi keramaian saat Hari Raya Idul Fitri. Puncak peringatan lebaran justru pada Lebaran Ketupat, yaitu setelah selesai puasa sunah Syawal. Serangkaian prosesi keberangkatan seseorang untuk pergi haji pun benar-benar menjadi prosesi panjang dan besar. Antusias masyarakat sangat besar untuk mengikuti proses panjang itu, dari pengajian yang diselenggarakan untuk keberangkatan, pada saat keberangkatan, dan menyambut kepulangan seseorang yang menunaikan ibadah haji. Ada anggapan dan keyakinan bahwa dalam menghantarkan seseorang pergi haji terdapat harapan dan doa untuk semoga mereka dapat menunaikan ibadah haji pada masa mendatang.

Selain itu, keyakinan akan kebesaran dan kekuatan Tuhan yang tercermin dalam cerita rakyat Monyeh adalah pada bagian:

...Pada saat Denda Winangsia sedang asyik melukis dan membuat syair itu, tiba-tiba datanglah angin kencang menyambar kertas itu. Angin membawa kertas itu terbang ke angkasa jauh melayang. Akhirnya, kertas itu jatuh di Taman Sari Kerajaan Indrasekar. Kedua lembar kertas itu tersangkut di tepi pancuran mandi putra raja. Kebetulan putra Raja Indrasekar, Raden Witarasari, pergi mandi bersama adiknya, Raden Kitapmuncar. Para abdi dan pengiring lain ikut pula...

Bagian cerita itu menggambarkan adanya angin kencang yang dapat menerbangkan kertas lukisan Denda Winangsia sampai ke Taman Sari Kerajaan Indrasekar. Diceritakan Denda Winangsia membuat lukisan dirinya dan syair tentang kisah hidupnya itu di kerajaan Indrapandita yang terletak di wilayah Pulau Lombok, sedangkan kertas itu diterbangkan angin sampai ke wilayah Kerajaan Indrasekar yang terletak di Pulau Jawa. Ada pernyataan secara implisit dalam cerita itu bahwa semua itu bisa terjadi atas kehendak dan kebesaran Tuhan. Artinya, ada sebuah kekuatan besar yang telah Tuhan berikan sehingga angin tersebut dapat menerbangkan kertas lukisan dan syair Denda Winangsia dalam rentang jarak yang begitu jauhnya. Hal itu juga menunjukkan bahwa apa 
yang tidak terjangkau oleh logika manusia mungkin sekali bisa terjadi apabila Tuhan berkehendak karena Tuhan mempunyai kekuatan yang bersifat lebih di atas segalanya.

Pada cerita rakyat Monyeh, terdapat beberapa bagian yang menggambarkan keyakinan akan kebesaran Tuhan, bagian-bagian itu adalah sebagai berikut.

...Setelah sadar, Raden Witarasari segera pulang ke istana untuk melaporkan kepada ayahandanya. Ia meminta kepada adiknya yang sakti, Kitapmuncar, untuk dibuatkan kapal dagang yang besar. Raden Kitapmuncar menyanggupi kehendak putra mahkota. Kemudian, Raden Kitapmuncar mengeluarkan cemeti wasiatnya. Sekali lecut terbelahlah alun-alun di depan istana menjadi sungai besar. Dari lecutan kedua tiba-tiba tercipta sebuah kapal dagang besar bertiang tiga. Haluannya berukir kepala singa lengkap dengan layar dan bendera. Kapal itu tidak ubahnya kapal dagang kompeni...

Pada bagian itu, diceritakan bahwa Raden Kitapmuncar dengan cemeti wasiatnya dapat membuat terbelahnya alun-alun di depan istana menjadi sungai besar dan dari lecutan kedua tercipta sebuah kapal dagang besar bertiang tiga yang haluannya berukir kepala singa lengkap dengan layar dan bendera. Raden Kitapmuncar sangat terkenal sakti dan dapat mewujudkan semua itu. Sebagai manusia biasa tentu menjadi hal yang mustahil dapat melakukan hal-hal yang di luar logika manusia itu. Namun, dengan kesaktian yang dimiliki, Raden Kitapmuncar dapat melakukan hal tersebut. Tentu saja semua hal itu dapat terwujud atas bantuan dan pertolongan Tuhan. Meskipun Raden Kitapmuncar memiliki kesaktian tinggi, semua itu bisa menjadi sesuatu yang tidak berarti apabila tidak ada campur tangan Tuhan. Kebesaran Tuhan yang ditunjukkan pada cerita rakyat itu menggambarkan bagaimana masyarakat meyakini benar akan kebesaran Tuhan seperti yang dituntunkan oleh ajaran Islam.

Bagian lain dari cerita rakyat Monyeh yang juga menunjukkan adanya keyakinan akan kebesaran Tuhan adalah:

...Jual beli di pantai itu sangat ramai. Raja membeli bermacam-macam barang mahal untuk delapan putrinya. Saat itu datanglah Rangda Sayoman ingin membeli barang berharga murah. Raden Kitapmuncar yang sakti segera tahu bahwa Rangda Sayoman adalah pengasuh Denda Winangsia. Ia kemudian cepat melapor ke kapal. Mendengar berita bahwa pengasuh Winangsia mencari 
barang berharga murah sekitar enampuluh kepeng, Raden Witarasari langsung mengubah dirinya menjadi kera (dalam bahasa Sasak disebut monyeh)...

Pada bagian itu, diceritakan bagaimana Raden Witarasari mengubah dirinya menjadi wujud seekor kera atau dalam bahasa Sasak disebut monyeh. Kalau kita berpikir dengan logika manusia tentu tidak memungkinkan seorang manusia mengubah wujudnya menjadi seekor kera. Dalam cerita itu disebutkan bahwa Raden Witarasari akhirnya bisa mengubah wujud dirinya menjadi kera. Hal itu tidak mungkin dapat menjadi kenyataan apabila tidak ada campur tangan kekuatan dan kebesaran Tuhan. Kejadian berubahnya wujud Raden Witasari itu telah menunjukkan adanya keyakinan bahwa Tuhan itu benar-benar ada dengan segala kekuatan dan kebesarannya, dan apabila Tuhan berkehendak akan sesuatu maka terjadilah. Segala keyakinan akan kebesaran Tuhan yang terdapat dalam cerita rakyat Monyeh itu merupakan refleksi dari keyakinan dalam kehidupan masyarakat etnis Sasak yang sesuai dengan ajaran Islam yang dianutnya.

\subsection{Hakikat Hubungan Manusia dengan Sesama}

Dalam menjalani kehidupan ini, manusia merupakan makhluk individu sekaligus makhluk sosial. Sebagai individu, seorang manusia mempunyai hakhak pribadi dalam kehidupannya, tapi perlu disadari bahwa manusia hidup dengan individu lain yang membentuk kelompok sosial. Pada akhirnya dalam kenyataan hidup, kepentingan individu itu berbenturan dengan kepentingan sosial. Jadi seorang manusia sudah semestinya menyadari bahwa dirinya bukan semata-mata sebagai makhluk individu, tetapi juga sebagai makhluk sosial. Sebagai makhluk sosial, dalam keberlangsungan kehidupan bersama, seorang manusia dituntut untuk mempunyai rasa tolong menolong, rasa menyayangi, toleransi, menghormati dan menghargai serta berempati pada sesamanya sehingga tercipta kerukunan hidup bersama dalam suatu kelompok masyarakat.

\section{a. Kasih sayang}

Pada cerita rakyat Monyeh ada bagian-bagian yang menunjukkan bagaimana hubungan manusia dengan sesama yang terjalin baik seperti berikut. ...Hari-hari Ratna Ayu Wideradin atau Denda Winangsia dihabiskan berdua dengan inang asuhnya. Suatu hari, Denda Winangsia minta kepada inangnya untuk membelikan dua lembar kertas. Harga kertas itu dua puluh lima kepeng. 
Rangda Sayoman yang sangat menyayangi Denda Winangsia segera pergi membelikan apa yang dimintanya. Setelah itu, kertas itupun diserahkan kepada sang putri. Denda Winangsia segera membuat lukisan dirinya pada kertas itu. Lukisannya sangat indah, persis dengan keadaan aslinya.

Bagian cerita di atas menceritakan bahwa Denda Winangsia menghabiskan hari-harinya bersama inang asuhnya, yaitu Rangda Sayoman. Diceritakan juga Rangda Sayoman sangat menyayangi Denda Winangsia. Hal ini menunjukkan bahwa sebagai manusia kita seharusnya bisa saling menyayangi, tidak berbatas pada orang-orang yang mempunyai pertalian darah saja. Apa yang telah digambarkan oleh Rangda Sayoman dan Denda Winangsia sangat berbeda keadaanya dengan sikap orangtua Denda Winangsia dan juga kedelapan saudaranya yang justru sangat tidak menyukai keberadaan Denda Winangsia.

\section{b. Persaudaraan}

Sikap dan perbuatan yang tidak terpuji ini tentu dapat menjadi gambaran bahwa sifat iri, dengki dan kebencian pada saudara sendiri pada akhirnya nanti tidak akan berbuah pada kebaikan. Sikap ayahanda dan kedelapan saudara Denda Winangsia yang membenci dan menyia-nyiakan dirinya itu sangat jauh berbeda keadaanya dengan gambaran kehidupan persaudaraan yang ditunjukkan oleh Raja Indrasekar beserta permaisuri dan anak-anaknya. Dari awal sampai akhir cerita tidak diceritakan adanya ketidakcocokan di antara keluarga kerajaan Indrasekar. Semua yang diceritakan bagaimana di antara mereka saling memberikan perhatian, dukungan, dan pertolongan satu dengan yang lainnya. Hubungan baik terjalin antara Raden Witarasari sebagai seorang putra mahkota dengan Raden Kitapmuncar sebagai penawing atau pangeran kelas dua. Tidak ada perasaan iri dan saling berebut status di antara mereka, justru sebaliknya, mereka sebagai saudara sangat rukun dan bisa saling membantu dan melengkapi satu sama lain, seperti yang terdapat pada bagian cerita berikut.

...Setelah sadar, Raden Witarasari segera pulang ke istana untuk melaporkan kepada ayahandanya. Ia meminta kepada adiknya yang sakti, Kitapmuncar, untuk dibuatkan kapal dagang yang besar. Raden Kitapmuncar menyanggupi kehendak putra mahkota. 
Dalam kehidupan nyata etnis Sasak yang mayoritas menganut ajaran Islam, sudah semestinya dalam menjalani kehidupan sehari-hari dilandasi oleh ajaran yang menuntun ke arah kebaikan. Hal itu juga terlihat bagaimana sikap seseorang harus menempatkan diri di depan saudara yang lebih tua, kepada orangtua, kepada tetangga, kepada tuan guru, dan sebagainya. Contoh nyata apabila seseorang bertemu dengan saudara yang lebih tua maka yang muda mengulurkan tangan untuk berjabat tangan serta mencium tangan saudara yang lebih tua. Hal itu menunjukkan rasa hormatnya kepada saudara yang lebih tua, begitu pula kepada kedua orangtua, kepada tuan guru ataupun orang yang dituakan.

Pada masyarakat Sasak, ada juga sebutan semeton yang berarti saudara. Penyebutan semeton ini tidak berarti karena orang tersebut merupakan saudara yang mempunyai hubungan darah. Penyebutan semeton juga digunakan untuk menyebut teman atau seseorang yang dikenal dekat dan sudah dianggap seperti saudara sendiri.

\section{c. Empati dan menolong sesama}

Selain mempunyai rasa sayang, rasa saling menghargai, dan saling melengkapi satu sama lain digambarkan pula bahwa Raden Witarasari seorang putra mahkota yang mempunyai kelembutan hati dan empati yang besar kepada sesama. Hal ini terlihat jelas bagaimana perasaan sedih Raden Witarasari bahkan sampai pingsan karena terlalu sedih ketika membaca syair ungkapan

perasaan hati Denda Winangsia atas perlakuan ayahanda dan kedelapan saudaranya, seperti terlihat pada penggalan cerita berikut:

Sesampai di Taman Sari pergilah Raden Witarasari menuju pancuran. Gambar dan syair Denda Winangsia ditemukan Raden Witarasari. Lalu, ia memperhatikan lukisan itu dan dibacanya syair ia memperhatikan lukisan itu dan dibacanya syair yang tertera di kedua lembar kertas itu. Tidak terkira sedih hati Witarasari sampai ia tidak sadarkan diri. Raden Kitapmuncar segera menolongnya dan dibacanya pula surat itu. Tahulah ia bahwa Raden Witarasari pingsan karena sedih setelah mengetahui perihal sepupunya di negeri Indrapandita. Sudah lama ia mendapatkan kabar dari para nahkoda kapal bahwa ada seorang putri raja yang amat cantik. Putri raja itu disiasiakan oleh ayahandanya karena selalu difitnah oleh kedelapan saudaranya. 
Dalam kehidupan bermasyarakat, seorang manusia harus menyadari kodratnya sebagai makhluk sosial. Dalam keseharian hidup bermasyarakat, seseorang dituntut untuk peka pada lingkungan sekitar dan mempunyai rasa empati terhadap apa yang dirasakan oleh orang lain sehingga pada akhirnya terwujud sikap tolong menolong antarsesama. Dalam kehidupan sosial etnis Sasak, rasa empati itu ditunjukkan ketika ada teman atau tetangga yang mengalami musibah, misalnya ada keluarga yang sakit atau meninggal, maka sebagai tetangga sudah semestinya ikut menjenguk serta memberikan dukungan dan doa untuk yang sakit atau keluarganya. Rasa empati tidak hanya diberikan ketika terjadi musibah seperti itu, tapi juga ditunjukkan ketika ada keluarga yang sedang bersuka cita, seperti ada acara hajatan, kelahiran putra-putri, keberangkatan haji, dan sebagainya. Sebagai bentuk perhatian dan dukungan maka sesama warga saling berkunjung, memberikan bantuan, dan juga doa. Semua hal yang dilakukan itu sesuai dengan ajaran Islam yang dianut masyarakat Sasak.

\section{Penutup}

Etnis Sasak mempunyai ragam sastra yang tumbuh dan berkembang di masyarakat. Setiap ragam sastra tersebut sudah pasti mempunyai nilai-nilai yang mencerminkan budaya etnis Sasak itu sendiri. Nilai-nilai budaya yang terdapat dalam cerita rakyat dapat dihubungkan dengan lima hakikat dasar kehidupan manusia, yaitu hubungan manusia dengan Tuhan, hakikat hubungan manusia dengan sesama, hakikat hubungan manusia dengan waktu, hakikat hubungan manusia dengan karya, dan hakikat hubungan manusia dengan alam.

Tulisan ini menguraikan nilai-nilai budaya etnis Sasak dalam cerita rakyat Monyeh yang dihubungkan dengan hakikat dasar kehidupan manusia, yaitu hakikat hubungan manusia dengan Tuhan dan hakikat hubungan manusia dengan sesama. Hakikat hubungan manusia dengan Tuhan dapat direfleksikan dalam banyak hal, antara lain keyakinan manusia akan Tuhan dengan segala kebesarannya dan melakukan perbuatan-perbuatan kebaikan yang mengacu pada segala perintah serta menjauhi perbuatan-perbuatan yang menjadi larangan Tuhan sesuai petunjuk yang terdapat pada kitab suci. Etnis Sasak yang mayoritas menganut Islam dalam kehidupan bermasyarakat sangat kental dengan nilai-nilai keagamaan. Nilai budaya yang berhubungan dengan hakikat hubungan sesama manusia terefleksi dalam sikap atau perbuatan, yaitu rasa 
Kearifan Lokal Etnis Sasak... (Nuryati) | 114

saling menyayangi, sikap yang menjunjung persaudaraan, sikap menolong dan empati antara seseorang dengan orang lain dalam masyarakat.

\section{DAFTAR PUSTAKA}

Alaini, Nining Nur. 2009. Nilai Budaya Etnis Sasak di Pulau Lombok yang Tercermin dalam Folklor Lisannya. Mataram: Kantor Bahasa Provinsi NTB

Bungin, Burhan. 2005. Analisis Data Penelitian Kualitatif. Jakarta: PT RajaGrafindo Persada.

Dananjaja, James. 2001. Foklor Indonesia: Ilmu Gosip, Dongeng, dan lainlain. Jakarta: Pustaka Utama Grafiti.

Eddy, Nyoman Tusthi. 1991. Kamus Istilah Sastra Indonesia. Ende: Nusa Indah.

Krisna, Eva et al. 2001. Sastra Lisan Saluang. Padang: Balai Bahasa Padang

Liliweri, Alo. 2005. Prasangka dan Konflik Komunikasi Lintas Budaya Masyarakat Multikultur. Yogyakarta: LKiS

Windia, Lalu. 2006. Manusia Sasak. Bagaimana Menggaulinya? Yogyakarta: Genta Pres. 